\title{
Weekly Seasonal Agro Climatic Potentialities of India and Climate Change in Extremities
}

\author{
Sivaram $B^{1^{*}}$ and Sarma AALN ${ }^{2}$ \\ ${ }^{1}$ Department of Mathematics, Sri Venkateswara College of Engineering and Technology, Chittoor, India \\ ${ }^{2}$ Andhra University, Visakhapatnam, India
}

*Corresponding author: Sivaram B, Department of Mathematics, Sri Venkateswara College of Engineering and Technology, Chittoor, India, Tel: 09440964038; E-mail: sivaramboppe@yahoo.co.in

Received date: Jan 20, 2017; Accepted date: Mar 14, 2017; Published date: Mar 24, 2017

Copyright: (c) 2017 Sivaram B, et al. This is an open-access article distributed under the terms of the Creative Commons Attribution License, which permits unrestricted use, distribution, and reproduction in any medium, provided the original author and source are credited.

\begin{abstract}
The Ocean atmospheric interaction such as EI Nino and Southern Oscillation (ENSO) and LaNina and Southern Oscillation (LNSO) plays an important role in monsoon performance and in turn it affects the agro climatic potentialities. The present investigation addresses the impact of the ENSO and LNSO in the periods 1951-1980, 1981-1990 and 1992-1998 on the agro climatic potentialities such as precipitation, potential and actual evapotranspiration, surplus, indices such as moisture, humid and aridity, moisture adequacy, soil wetness of India and selected stations from the climate spectrum of India in different seasons in dry and wet years along with ENSO and LNSO situations on a mean weekly basis. The climate status of All India enriched to fourth humid (B4) and third humid (B3) status during the monsoon seasons of the study periods 1981-1990 and 1992-1998 respectively. During the retrieval of the monsoon All India climate status depleted to moist sub humid (C2) in the years 1992-1998. In the cold weather season of 1992-1998 the climate status depleted to dry sub humid (C1) and experienced aridity in the years 1981-1991. All India climate status enriched to semi aridity (D) during the hot weather season of 1992-1998 compared to the normal status of the same season.
\end{abstract}

Keywords: Humidity; Aridity; Moisture indices; Soil moisture; Adequacy

\section{Introduction}

The past and current anthropogenic land use changes have lead the way for the significant variations of land surface dynamic parameters such as surface albedo, surface resistance, vegetation index and vegetation fractional coverage. These variations resulted in large changes in surface energy and water balance that modulate atmospheric circulation over the region. In understanding the atmospheric and climatic changes, it is very important to understand these variations. India being an agrarian country, the climate change plays an important role in monitoring the crop performance and Indian economy.

Gadgil [1] reported the climatic changes and its impact on agricultural production in India.

The activity of summer monsoon rainfall has a strong bearing on many climate teleconnections. In 1982/83 El Niño resulted in severe drought and flood damage in several countries. This year, first season crops have been affected by drought in most Central American and some Caribbean countries [2].

The ENSO and LNSO effects the economics of the agriculture due to shortening and enlargement of monsoon duration and its performance. The abnormal loss to the agriculture by these two events is reported by Richard et al. [3].

Das and Goankar [4] investigated the effects of the climatic environment on three different varieties of paddy using the crop coefficient in different stages of growth, the consumptive uses and radiation use efficiency.

Kashyaji [5] reported the influence of meteorological parameters such as temperature, rainfall, relative humidity, and bright sunshine hours on the possible growing season and crop performance in rainfed cropping system in a given area. Deng [6] discussed about the impacts of ENSO on rice production.

Sarma and Vizayabhaskar [7] studied and reported that ENSO reduces the agriculture production and yields of major crops, while LNSO increases the agriculture production and yields during the Kharif season.

The influence of seasonal teleconnections such as El Nino and Southern Oscillations patterns on cryosphere of Antarctica and Himalayan regions have been discussed by Krishna et al. [8].

Various aspects of Indian summer monsoon activity, El Nino and Southern Oscillation (ENSO) and LaNina \& SO (LNSO) relationship have been investigated by several research workers to name a few [9-13].

Bhalme et al. [14], Sarker [15], Chaudhury and Mhasawade [16] have investigated association between El Nino, monsoon rainfall and droughts in India.

The present investigation addresses the climate change, variations in precipitation, potential and actual evapotranspiration, surplus, indices such as moisture, humid and aridity, moisture adequacy, soil wetness, of India and selected stations from the climate spectrum of India in different seasons during the dry and wet situations accompanied by ENSO and LNSO in the periods 1951-1980, 1981-1990 and 1992-1998, 
Page 2 of 11

which gives a better resolution of effects of these events on the agriculture sector of India on a weekly basis.

\section{Material and Methodology}

The revised water balance concept of Thornthwaite and Mather [17] is followed in computing the water budget elements for 90 stations that are drawn from varied geographical settings of India. The Normals of Agro climatic Observatories India (India Meteorological Department) and the data supplied by the India Meteorological Department, PUNE on a weekly basis for the standard monsoon period (22nd week to 39th week) [18], retrieval of monsoon, cold and hot weather seasons for the periods 1951-1980, 1981-1990 and 1992-1998 have been used to arrive at the agro climatic indices.

The mean weekly climatic indices such as humidity (Iwh \%), aridity (Iwa \%), moisture indices (Iwm \%) are derived from the basic water budget elements. Mean weekly humidity and aridity indices in four seasons-monsoon, retrieval of monsoon, cold and hot weather seasons of All India as well as selected stations will reflect the seasonal mean weekly affectivity of moisture. These indices have been obtained for the study of moist and dry climates respectively in extreme dry and wet years accompanied by ENSO and LNSO. The lowest and highest moisture indices of All India are the two ends of the moisture status. A year in which moisture index is low will be considered as a dry year which may be a consequence of poor performance of the south west monsoon. Hence these dry and wet years are the two extremities of the moisture status, which may be accompanied by El Nino and Southern Oscillation (ENSO) or La Nina and Southern Oscillation (LNSO). The absence of moisture leads to drought. The year in which the moisture index is high will be a wet year that may be due to the good amount of rainfall. The presence of moisture is necessary for the growth of plants and cultivation.

In determining the moisture status of All India, the revised expression of moisture index [19] is followed and is obtained for four seasons of the year on mean weekly climate concept.

The maximum water holding capacity of a location will depend upon the structure and texture of the soil of the location. The maximum water holding capacity of a soil against the pull of gravity is called field capacity (Fc mm). Field capacity values are assigned depending upon the root zone of the crops and soil characteristics of the selected stations.

The soil wetness of All India as well as the selected stations from the climate spectrum of India is estimated as the percentage ratio of water storage (St $\mathrm{mm})$ to field capacity $(\mathrm{Fc} \mathrm{mm})$.

Soil wetness $(\mathrm{Swt})(\%)=(\mathrm{St} / \mathrm{Fc}) \times 100$

The index of moisture adequacy is the ratio of actual evapotranspiration to potential evapotranspiration expressed as a percentage.

In climate classification moisture index plays an important role. So much of information is available for the climate classification, but the scheme which was given by Thornth waite was extended for climate classification on a weekly basis during the Hot weather season (March to May), South west monsoon season (June to September), retreating south west monsoon season (October to November) and Cold Weather Season (December to February) of the study, which is presented here under:

$$
\mathrm{I}_{\mathrm{m}}=\mathrm{I}_{\mathrm{h}}-\mathrm{I}_{\mathrm{a}}
$$

Where $\mathrm{I}_{\mathrm{h}}=$ Humidity index, $\mathrm{I}_{\mathrm{a}}=$ Aridity index, all being percentages.

\section{Results and Discussion}

\section{Mean weekly seasonal climate change of India}

It is evident from the present investigation that the normal (1951-1980) hydrologic regime of All India is first humid climate (B1), during the monsoon period with a mean weekly precipitation of 57 $\mathrm{mm}$ and potential evapotranspiration of $36 \mathrm{~mm}$ that could result in a moderate water surplus of $14 \mathrm{~mm}$ with a water deficit of $1 \mathrm{~mm}$. The soils are at $98 \%$ moisture adequacy with a $74 \%$ of wetness in general (Table 1). The climate status of All India during the retrieval of monsoon is shifted to dry sub humid (C1) with a mean weekly precipitation of $17 \mathrm{~mm}$ and potential evapotranspiration of $26 \mathrm{~mm}$ which resulted a water deficit of $2 \mathrm{~mm}$. The soils are at $92 \%$ adequate with $80 \%$ wetness. Climate status has become semi-arid (D) during cold weather season (December to February) with a dip in the rainfall to $4 \mathrm{~mm}$, water need to $12 \mathrm{~mm}$, water surplus to $0 \mathrm{~mm}$ accompanied with an increase in water deficit to $7 \mathrm{~mm}$ per week. The soils are $48 \%$ adequate with $20 \%$ wetness during this period.

During the hot weather season (March-May), with a mean weekly precipitation of $11 \mathrm{~mm}$ and potential evapotranspiration of $38 \mathrm{~mm}$ that resulted a deficit of $28 \mathrm{~mm}$ with no water surplus, the All India climate depleted to aridity (E) with $27 \%$ soil moisture adequacy, accompanied by $1 \%$ wetness.

The hydrological regime of All India during the monsoon period of the decade 1981-1991 is fourth humid (B4) with mean weekly rainfall of $73 \mathrm{~mm}$ and potential evapotranspiration of $35 \mathrm{~mm}$ that could result in a surplus of $30 \mathrm{~mm}$ with no water deficit. The soils are adequate at $99 \%$ and wet by $82 \%$. During the retrieval of monsoon, India experienced dry sub humid climatic (C1) status with a mean weekly precipitation of $18 \mathrm{~mm}$ and a potential evapotranspiration of $26 \mathrm{~mm}$ that resulted a water deficit of $1 \mathrm{~mm}, 95 \%$ adequacy and $86 \%$ wetness.

In the cold weather conditions with a rainfall of $4 \mathrm{~mm}$ and water need of $13 \mathrm{~mm}$ per week resulted to a soil moisture adequacy of $64 \%$, with $44 \%$ soil wetness. As a result All India climate shifted to semi-arid (D) in cold weather season. A mean weekly precipitation of $9 \mathrm{~mm}$ with a potential water need of $39 \mathrm{~mm}$ which resulted to deficit of $27 \mathrm{~mm}$ accompanied by an adequacy of $31 \%$ and a wetness of $10 \%$ forced the All India climatic status to shift to aridity (E).

During the study period of 1992-1998, in the monsoon season All India witnessed a mean weekly precipitation of $66 \mathrm{~mm}$, potential water need of $33 \mathrm{~mm}$ that result a deficit of $1 \mathrm{~mm}$ and water surplus of 25 $\mathrm{mm}$ with a soil moisture adequacy of $98 \%$ and $85 \%$ wetness of soils. As a result, All India climate witnessed third humid (B3). All India climate shifted to moist sub humid (C2) in the retrieval of monsoon period with $26 \mathrm{~mm}$ rainfall and potential evapotranspiration, $5 \mathrm{~mm}$ water surplus resulting $98 \%$ adequacy and $91 \%$ soil wetness. During the cold weather season All India experienced dry sub humid (C1) climatic status due to a rainfall of $6 \mathrm{~mm}$ and $13 \mathrm{~mm}$ water need.

Though the rainfall is depreciated by $60 \mathrm{~mm}$ from the monsoon period the soils are $70 \%$ adequate with $52 \%$ wetness. In the hot weather season a precipitation of $12 \mathrm{~mm}$ with water need $36 \mathrm{~mm}$ resulted a deficit of $21 \mathrm{~mm}$ and forced the climate of All India to semiarid (D). During this season the soils are wet by $12 \%$ with an adequacy of $42 \%$. 


\begin{tabular}{|c|c|c|c|c|c|c|c|c|c|c|c|}
\hline Period & Season & $P(\mathrm{~mm})$ & PE (mm) & $\mathrm{AE}(\mathrm{mm})$ & $D(\mathrm{~mm})$ & $S(m m)$ & Iwh (\%) & Iwa (\%) & Iwm (\%) & Wetness (\%) & Adequacy (\%) \\
\hline \multirow[b]{4}{*}{$1951-1980$} & June-Sept & 57 & 36 & 35 & 1 & 14 & 40 & 2 & 38 (B1) & 74 & 98 \\
\hline & Oct-Nov & 17 & 26 & 24 & 2 & 0 & 0 & 8 & $-8(C 1)$ & 80 & 92 \\
\hline & Dec-Feb & 4 & 12 & 5 & 7 & 0 & 0 & 52 & $-52(D)$ & 20 & 48 \\
\hline & Mar-May & 11 & 38 & 11 & 28 & 0 & 0 & 73 & $-73(E)$ & 1 & 27 \\
\hline \multirow[b]{4}{*}{$1981-1991$} & June-Sept & 73 & 35 & 34 & 0 & 30 & 90 & 1 & 89 (B4) & 82 & 99 \\
\hline & Oct-Nov & 18 & 26 & 25 & 1 & 0 & 0 & 5 & $-5(C 1)$ & 86 & 95 \\
\hline & Dec-Feb & 4 & 13 & 8 & 5 & 0 & 0 & 36 & $-36(D)$ & 44 & 64 \\
\hline & Mar-May & 9 & 39 & 12 & 27 & 0 & 0 & 69 & $-69(E)$ & 10 & 31 \\
\hline \multirow[b]{3}{*}{$1992-1998$} & June-Sept & 66 & 33 & 33 & 1 & 25 & 76 & 2 & 74(B3) & 85 & 98 \\
\hline & Oct-Nov & 26 & 26 & 25 & 0 & 5 & 16 & 2 & $14(\mathrm{C} 2)$ & 91 & 98 \\
\hline & Dec-Feb & 6 & 13 & 9 & 4 & 0 & 0 & 30 & $-30(C 1)$ & 52 & 70 \\
\hline
\end{tabular}

Table 1: Seasonal water budget elements on mean weekly basis-all India extremities.

From the above analysis it can be concluded that the All India climate is normally first humid (B1), which is enriched to fourth (B4) and third humid (B3) during the monsoon season of 1981-1991 and 1992-1998 respectively. In the retrieval of monsoon season, All India experienced dry sub humid (C1) climate in the years 1951-1980 and 1981-1991, while the climate status improved to moist sub humid (C2) in 1992-1998. The All India climate depleted to semiarid (D) during the cold weather seasons of 1951-1980 and 1981-1991, enriched to dry sub humid (C1) in 1992-1998. The climate status enriched to semiarid (D) in the hot weather seasons of 1981-1991 and 1992-1998 compared to the normal status of aridity (E).

\section{Mean weekly seasonal climate change of per humid zone (A) in extremities}

Tocklai: It is evident that the water surplus of Tocklai that hails from per humid zone, during the monsoon season of the extreme wet year (1987) is only $1 \mathrm{~mm}$ more than the normal, with $47 \%$ depreciation during the dry year (1988). As a consequence, the climate in the extreme wet (1987) and dry (1988) years has taken a shift down ward into humid (B) climates with a moisture status of fourth humid (B4) and third humid (B2) respectively. The soil moisture adequacy and wetness depreciated by $1 \%$, and $6 \%$ respectively in the dry year, but adequacy maintained its normality with a $2 \%$ decrease in wetness in the extreme wet year (1987). It is also observed that the climate status taken a shift to dry sub humid (C1) from the normal status of moist sub humid, during the monsoon retrieval period in dry and wet years due to an increase in potential water need by $4 \%$ with a depreciation in rainfall by $68 \%$ from the normal. In this season soil moisture adequacy and wetness reduced by $15 \%$ and $19 \%$ respectively during the dry year, $25 \%$ and $33 \%$ depreciation of adequacy and wetness in the wet year.

During the cold weather season, Tocklai maintained its normal status of dry sub humid (C1) during the dry and wet years. But the soil moisture adequacy and wetness showed a depreciation of $20 \%$ in each during dry year. The wet year experienced a depreciation of $17 \%$ adequacy and $8 \%$ wetness. During the hot weather season Tocklai maintained its normal moist sub humid (C2) status in both the extremities.

Karjat: It is observed that during the monsoon season of a dry year (1987), which is also an ENSO year, there is $43 \%$ depreciation in the water surplus, which is due the $35 \%$ shortage of rainfall from the normal. As a result $8 \%$ depreciation in soil moisture adequacy and $2 \%$ decrease in wetness are observed. During the retrieval of monsoon season due to a depreciation of $29 \%$ in rainfall accompanied with an increase in potential water need of $9 \%$, resulted a drop in the soil moisture adequacy by $25 \%$ and soil wetness by $29 \%$ from the normal. As a result climatic status of Karjat forced to shift to dry sub humid (C1). In the cold weather and hot weather seasons the rain fall showed further depreciation from the normal and hence climate experienced aridity (E), though this station hails from the per humid zone. As a consequence, during these seasons adequacy showed a fall of $21 \%, 80 \%$ and wetness dropped by $37 \%, 50 \%$ in cold and hot weather seasons respectively.

During the summer monsoon season of the wet year (1983), Karjat has experienced a water surplus of $173 \mathrm{~mm}$, which is $20 \%$ increase, with a rise in the rainfall by $14 \%$ from the normal. Witnessed an $8 \%$ increase in the water surplus with a rise in rainfall by $6 \%$ from the normal (Table 2). In this season, soil wetness depleted by $5 \%$ in association with $10 \%$ drop in soil moisture adequacy. Karjat experienced moist sub humid status (C2) in the retrieval of monsoon season due to less amount of rainfall and more water need.

Karjat maintained its Arid (D) status during the cold and hot weather seasons due to a drop in the rainfall that results no surplus. The soil moisture adequacy and wetness dropped by $4 \%$ and $11 \%$ in the cold weather seasons. The variations in the water surplus might be due to the variations in the monsoon activity. It is interesting to observe that during the monsoon period of dry year, coupled with ENSO there is a considerable compression in the wetness as well as the amount of rainfall. In the rest of the extremities the wetness prevailed throughout the monsoon period, which might be due to the higher amounts of rainfall caused by the active monsoon circulation pattern. Throughout the period of study the moisture status of Karjat is 
Citation: Sivaram B, Sarma AALN (2017) Weekly Seasonal Agro Climatic Potentialities of India and Climate Change in Extremities. J Climatol

Page 4 of 11

consistent and maintained its per humid (A) status in monsoon season but shifted to moist sub humid (C2) and dry sub humid (C1)in the retrieval and then dropped to Arid (E) in the cold and hot weather seasons during the Dry and Wet years.

\begin{tabular}{|c|c|c|c|c|c|c|c|c|c|c|c|c|}
\hline Station & Period & Season & $\begin{array}{l}P \\
(\mathrm{~mm})\end{array}$ & $\begin{array}{l}\text { PE } \\
(\mathrm{mm})\end{array}$ & $\begin{array}{l}\mathrm{AE} \\
(\mathrm{mm})\end{array}$ & $\begin{array}{l}\mathrm{D} \\
(\mathrm{mm})\end{array}$ & $\begin{array}{l}\mathrm{S} \\
(\mathrm{mm})\end{array}$ & Iwh (\%) & Iwa (\%) & Iwm (\%) & $\begin{array}{l}\text { Wetness } \\
(\%)\end{array}$ & $\begin{array}{l}\text { Adequacy } \\
\text { (\%) }\end{array}$ \\
\hline \multirow[t]{12}{*}{ Tocklai } & $1951-1980$ & June-Sept & 75 & 37 & 37 & 0 & 38 & 107 & 0 & $107(A)$ & 100 & 100 \\
\hline & & Oct-Nov & 19 & 24 & 23 & 1 & 3 & 8 & 6 & $3(\mathrm{C} 2)$ & 88 & 94 \\
\hline & & Dec-Feb & 5 & 8 & 7 & 1 & 0 & 0 & 11 & $-11(C 1)$ & 66 & 89 \\
\hline & & Mar-May & 41 & 28 & 27 & 1 & 7 & 20 & 3 & $17(\mathrm{C} 2)$ & 77 & 97 \\
\hline & Dry year (1988) & June-Sept & 55 & 38 & 37 & 0 & 20 & 54 & 1 & 53(B2 ) & 94 & 99 \\
\hline & & Oct-Nov & 19 & 25 & 22 & 3 & 4 & 13 & 15 & $-1(\mathrm{C} 1)$ & 81 & 85 \\
\hline & & Dec-Feb & 7 & 9 & 6 & 2 & 0 & 0 & 29 & $-29(C 1)$ & 53 & 71 \\
\hline & & Mar-May & 42 & 29 & 27 & 2 & 6 & 16 & 6 & $10(\mathrm{C} 2)$ & 69 & 94 \\
\hline & Wet year (1987) & June-Sept & 76 & 37 & 37 & 0 & 39 & 99 & 0 & 99(B4) & 98 & 100 \\
\hline & & Oct-Nov & 6 & 25 & 20 & 5 & 0 & 0 & 25 & $-25(C 1)$ & 67 & 75 \\
\hline & & Dec-Feb & 4 & 9 & 6 & 2 & 0 & 0 & 27 & $-27(C 1)$ & 61 & 73 \\
\hline & & Mar-May & 35 & 26 & 26 & 1 & 3 & 8 & 4 & $4(\mathrm{C} 2)$ & 84 & 96 \\
\hline \multirow[t]{12}{*}{ Karjat } & $1951-1980$ & June-Sept & 185 & 34 & 33 & 1 & 144 & 439 & 2 & $437(A)$ & 87 & 98 \\
\hline & & Oct-Nov & 17 & 32 & 26 & 6 & 2 & 6 & 20 & $-14(C 1)$ & 70 & 80 \\
\hline & & Dec-Feb & 1 & 18 & 4 & 14 & 0 & 0 & 77 & $-77(E)$ & 19 & 23 \\
\hline & & Mar-May & 1 & 44 & 2 & 42 & 0 & 0 & 95 & $-95(E)$ & 2 & 5 \\
\hline & & June-Sept & 121 & 36 & 32 & 4 & 81 & 238 & 10 & $229(\mathrm{~A})$ & 85 & 90 \\
\hline & Dry \& ENSO year (1987) & Oct-Nov & 12 & 35 & 21 & 13 & 3 & 7 & 40 & $-33(C 1)$ & 50 & 60 \\
\hline & & Dec-Feb & 3 & 20 & 3 & 16 & 0 & 0 & 82 & $-82(E)$ & 12 & 18 \\
\hline & & Mar-May & 0 & 45 & 0 & 44 & 0 & 0 & 99 & $-99(E)$ & 1 & 1 \\
\hline & Wet year (1983) & June-Sept & 211 & 34 & 30 & 4 & 173 & 542 & 12 & $530(A)$ & 83 & 88 \\
\hline & & Oct-Nov & 18 & 27 & 20 & 6 & 10 & 30 & 28 & $3(\mathrm{C} 2)$ & 66 & 72 \\
\hline & & Dec-Feb & 0 & 17 & 4 & 13 & 0 & 0 & 78 & $-78(E)$ & 21 & 22 \\
\hline & & Mar-May & 0 & 41 & 1 & 40 & 0 & 0 & 96 & $-96(E)$ & 3 & 4 \\
\hline
\end{tabular}

Table 2: Seasonal water budget elements on weekly basis-per humid zone (A)-extremities.

\section{Mean weekly seasonal climate change of humid zone (B) in extremities}

Adhartal: In the dry year (1996), the water surplus is decreased by $20 \mathrm{~mm}(69 \%)$ with an increase in water deficit by $10 \mathrm{~mm}(250 \%)$ from the normal due to sub normal rainfall, which was responsible for the shift of the station's climatic regime to the dry sub humid climate $(\mathrm{C} 1)$ type. Soils are adequate by $90 \%$ with wetness $70 \%$ during the monsoon season. The dry sub humid climate $(\mathrm{C} 1)$ prevailed during the retrieval and cold weather seasons and further depreciated to arid type (E) in the hot weather season.

In the wet year (1994), there was such a heavy rainfall which is nearly double the normal that caused to record an $80 \mathrm{~mm}$ water surplus, which is $51 \mathrm{~mm}(176 \%)$ more than the normal. As a result, the station's moisture status enriched to per humid (A) type. The soils are $75 \%$ wet with an adequacy of $85 \%$. During the retrieval of the monsoon, cold and hot weather seasons there is a depreciation of $100 \%$ surplus, due to the drop in rainfall by $100 \%, 75 \%$ and $0 \%$ in the respective seasons, which forced the climate status to shift Arid (E).

The soil wetness reduced by $51 \%, 62 \%$ and $40 \%$ in these seasons from their normal. As a result, the soil moisture adequacy also showed depletion by $55 \%, 73 \%$ and $50 \%$ from the corresponding normal in the retrieval, cold and hot weather seasons. 
Citation: Sivaram B, Sarma AALN (2017) Weekly Seasonal Agro Climatic Potentialities of India and Climate Change in Extremities. J Climatol Weather Forecasting 5: 199. doi:10.4172/2332-2594.1000199

Page 5 of 11

\begin{tabular}{|c|c|c|c|c|c|c|c|c|c|c|c|c|}
\hline Station & Period & Season & $P(\mathbf{m m})$ & $\begin{array}{l}\text { PE } \\
(\mathrm{mm})\end{array}$ & $\begin{array}{l}\text { AE } \\
(\mathrm{mm})\end{array}$ & $\mathrm{D}(\mathrm{mm})$ & $\mathrm{S}(\mathrm{mm})$ & $\begin{array}{l}\text { Iwh } \\
\text { (\%) }\end{array}$ & Iwa (\%) & Iwm (\%) & $\begin{array}{l}\text { Wetness } \\
(\%)\end{array}$ & Adequacy (\%) \\
\hline \multirow[t]{12}{*}{ Adhartal } & \multirow[t]{4}{*}{$1951-80$} & June-Sept & 68 & 37 & 33 & 4 & 29 & 91 & 10 & $81(B 4)$ & 70 & 90 \\
\hline & & Oct-Nov & 8 & 21 & 15 & 6 & 0 & 0 & 31 & $-31(C 1)$ & 55 & 69 \\
\hline & & Dec-Feb & 4 & 7 & 5 & 2 & 0 & 0 & 30 & $-30(C 1)$ & 37 & 70 \\
\hline & & Mar-May & 2 & 41 & 6 & 35 & 0 & 0 & 84 & $-84(E)$ & 10 & 16 \\
\hline & \multirow[t]{4}{*}{$\begin{array}{l}\text { Dry year } \\
(1996)\end{array}$} & June-Sept & 37 & 38 & 24 & 14 & 9 & 29 & 34 & $-5(C 1)$ & 50 & 66 \\
\hline & & Oct-Nov & 15 & 20 & 15 & 5 & 0 & 0 & 29 & $-29(C 1)$ & 62 & 71 \\
\hline & & Dec-Feb & 9 & 7 & 6 & 1 & 1 & 6 & 19 & $-13(C 1)$ & 69 & 81 \\
\hline & & Mar-May & 1 & 42 & 11 & 31 & 0 & 0 & 70 & $-70(E)$ & 25 & 30 \\
\hline & \multirow[t]{4}{*}{$\begin{array}{l}\text { Wet year } \\
(1994)\end{array}$} & June-Sept & 114 & 35 & 30 & 6 & 80 & 247 & 15 & 232(A) & 75 & 85 \\
\hline & & Oct-Nov & 0 & 21 & 7 & 14 & 0 & 0 & 69 & $-69(E)$ & 27 & 31 \\
\hline & & Dec-Feb & 1 & 8 & 2 & 6 & 0 & 0 & 81 & $-81(E)$ & 14 & 19 \\
\hline & & Mar-May & 2 & 42 & 3 & 39 & 0 & 0 & 92 & $-92(E)$ & 3 & 8 \\
\hline \multirow[t]{12}{*}{ Rudrur } & \multirow[t]{4}{*}{$1951-80$} & June-Sept & 48 & 34 & 31 & 3 & 9 & 31 & 8 & 23(B1) & 64 & 92 \\
\hline & & Oct-Nov & 11 & 24 & 19 & 4 & 0 & 0 & 21 & $-21(C 1)$ & 64 & 79 \\
\hline & & Dec-Feb & 2 & 15 & 5 & 10 & 0 & 0 & 61 & $-61(\mathrm{D})$ & 28 & 39 \\
\hline & & Mar-May & 4 & 45 & 5 & 39 & 0 & 0 & 88 & $-88(E)$ & 4 & 12 \\
\hline & \multirow[t]{4}{*}{$\begin{array}{l}\text { Dry year } \\
(1984)\end{array}$} & June-Sept & 37 & 34 & 25 & 10 & 9 & 25 & 27 & $-3(C 1)$ & 51 & 73 \\
\hline & & Oct-Nov & 10 & 23 & 13 & 10 & 0 & 0 & 47 & $-47(\mathrm{D})$ & 43 & 53 \\
\hline & & Dec-Feb & 0 & 15 & 3 & 13 & 0 & 0 & 80 & $-80(E)$ & 18 & 20 \\
\hline & & Mar-May & 0 & 45 & 1 & 44 & 0 & 0 & 98 & $-98(E)$ & 2 & 2 \\
\hline & \multirow[t]{4}{*}{$\begin{array}{l}\text { Wet year } \\
\text { (1989) }\end{array}$} & June-Sept & 81 & 31 & 28 & 3 & 45 & 150 & 9 & $141(\mathrm{~A})$ & 75 & 91 \\
\hline & & Oct-Nov & 0 & 22 & 13 & 9 & 0 & 0 & 45 & $-45(D)$ & 50 & 55 \\
\hline & & Dec-Feb & 3 & 14 & 4 & 10 & 0 & 0 & 71 & $-71(E)$ & 23 & 29 \\
\hline & & Mar-May & 4 & 42 & 5 & 37 & 0 & 0 & 84 & $-84(E)$ & 4 & 16 \\
\hline
\end{tabular}

Table 3: Seasonal water budget elements on weekly basis-humid zone (B)-extremities.

It is very interesting to note that in the extreme dry year, Adhartal that hails from humid zone shifted to dry sub humid $(\mathrm{C} 1)$ in monsoon season, and remained in the same status during retrieval of monsoon period and cold weather season. Climate status depleted to Aridity (E) in the hot weather season. During the wet year, Adhartal improved its moisture status to per humid (A) but witnessed aridity (E) during the retrieval, cold and hot weather seasons.

Rudrur: The mean weekly water budget elements in extremities are presented in the Table 2. It is evident that in the dry year (1984), there is an increase in the water deficit by $233 \%$ with depreciation in the rainfall by $23 \%$ from the normal that has forced the moisture status of Rudur to dry sub humid (C1) type from first humid (B1) status. There is a depreciation of $21 \%$ in soil moisture adequacy and $20 \%$ depreciation in soil wetness in monsoon season. In the retrieval of monsoon period, due to $100 \%$ depreciation in water surplus the moisture regime of Rudrur witnessed semi aridity (D), soil wetness and soil moisture adequacy decreased by $33 \%$ each from the respective normal. In the cold and hot weather seasons the climate status dropped to aridity (E) due to a drop in water surplus by $100 \%$, as a result the soil wetness and adequacy reduced by $36 \%, 49 \%$ and $50 \%, 83 \%$ respectively in the respective seasons of dry year (1984).

There is an increase in the water surplus by $36 \mathrm{~mm}$ (400\%) with a rise in the rainfall by $33 \mathrm{~mm}(69 \%)$ and depreciation in the water need by $3 \mathrm{~mm}(9 \%)$ from the respective normalcy, which have forced the 
moisture status to per humid (A), improved the soil wetness by $15 \%$ and adequacy by $1 \%$ from their respective normal during the monsoon season of the wet year (1989). A $100 \%$ drop in the water surplus due to $100 \%$ fall in the rain fall and $8 \%$ increase in the water need from the normal forced the climate status to shift to semi aridity (D), $22 \%$ decline in soil wetness and $30 \%$ decrease in soil moisture adequacy during the retrieval of monsoon season. Rudrur experienced Aridity (E) during the cold and hot weather seasons of wet year due to a drop in the rainfall with the absence of water surplus.

As a result, soil wetness and adequacy were dropped by $18 \%, 26 \%$ respectively in the cold weather season. There is a $33 \%$ increase in soil moisture adequacy during the hot weather season of the wet year.

It is observed that during the monsoon season of normal, dry and wet years Rudrur witnessed first humid (B1), dry sub humid (C1) and per humid(A) status respectively. During retrieval of monsoon season the climate status dropped to semi aridity (D), and during cold and hot weather seasons it has experienced aridity (E), both in dry and wet years respectively, which are due to the fluctuations in rainfall and surplus in the respective seasons.

\section{Mean weekly seasonal climate change of moist sub humid zone (C2) in extremities}

Agro climatic potentialities of Junagarh and Sabour representing the Moist sub humid zone (C2) in extreme situations such as dry and wet years in the monsoon, retrieval of monsoon, cold weather and hot weather seasons on a weekly basis are presented in the Table 3 .

Junagarh: It is observed that in the extreme dry year (1991), there is no water surplus due to sub normal rainfall and as a result there is a climatic shift to semiarid (D) type. The soil wetness and moisture adequacy depreciated by $41 \%$ and $36 \%$ from the respective normal during the monsoon season. In the retrieval of monsoon season also there is no water surplus due to subnormal rainfall, as a result Junagarh shifted its climate status to Aridity (E), with a decrease in soil wetness by $67 \%$ and soil moisture adequacy by $74 \%$ from the corresponding normal. During the cold weather season, the aridity (E) prevailed with soil wetness and adequacy of $6 \%$ and $7 \%$.

In the hot weather season also the climate status depleted to aridity (E) with $1 \%$ soil wetness and moisture adequacy. On the other hand, in the extreme wet year (1988), which is also happened to be the LNSO year, the water surplus is increased by $33 \mathrm{~mm}$ with an increase in the rainfall by $32 \mathrm{~mm}(71 \%)$ from the normal that resulted an improvement in the moisture status to third humid (B3) type accompanied by an increase in soil wetness by $6 \%$ and a decrease in adequacy by $13 \%$ from the corresponding normality during the monsoon season. In the retrieval of monsoon season though there is no water surplus due to absence of rainfall, the soils improved their wetness by $24 \%$ with no change in the moisture adequacy. The moisture status of this station dropped to semi aridity (D). In the rest of the seasons the climate status further dropped to aridity (E), but soil wetness showed an improvement of $11 \%$ with depreciation in the adequacy by $21 \%$ during the cold weather season and a decrease of $50 \%$ adequacy during the hot weather season of wet year and LNSO year (1988).

It is also evident from the Table 4 that in the dry year, the water deficit is $18 \mathrm{~mm}$, which is $12 \mathrm{~mm}$ (200\%) more than the normal (16 $\mathrm{mm}$ ) and in the wet year, the water deficit is $10 \mathrm{~mm}$, which is $4 \mathrm{~mm}$ (67\%) more than the normal. The variations in the water surplus and water deficits are due to the strong or weak monsoon circulation pattern over that region. It is worth mentioning that during the wet year there is a high amount of monsoon rainfall, which might be due to the impact of LNSO on the southwest monsoon circulation pattern. As a result, the climate status of Junagarh enriched to third humid (B3).

Sabour: In the dry year (1990), Sabour registered a water surplus of $6 \mathrm{~mm}$, though there is depletion in rainfall and an increase in water need from the respective normalcy during the monsoon season. The water deficits are increased by $5 \mathrm{~mm}$ during the monsoon season of the dry year. The soil wetness showed an improvement by $29 \%$ with a rise in adequacy by $17 \%$ during the monsoon season of the dry year. The climate status depleted to dry sub humid (C1) with $66 \%$ soil wetness and $82 \%$ moisture adequacy. During the retrieval of monsoon season, cold and hot weather seasons of dry year, the moisture status further depleted to semiarid (D).

The monsoon season of the extreme wet year (1987), experienced a water surplus of $58 \mathrm{~mm}$ due to abnormal rainfall of $103 \mathrm{~mm}$, which is twice that of normal rainfall, has enriched the station's moisture regime to per humid (A) (Table 4). The water deficit decreased by $1 \mathrm{~mm}$ from the normality. An increase in soil wetness by $41 \%$ in association with a rise in adequacy by $1 \%$ during the wet year from their corresponding normality is observed. In all other seasons such as retrieval of monsoon, cold and hot weather seasons of the wet year the moisture regime of this station experienced semi aridity (D).

The soils are wet by $46 \%, 41 \%$ and $19 \%$ during the retrieval of monsoon season, cold and hot weather seasons of wet years (1987) respectively. From the studies, it is evident that the climate status of Sabour enriched to Per humid (A) during the monsoon period of wet year (1987) and depleted to dry sub humid (C1) during the monsoon season of dry year (1990).

\section{Mean weekly seasonal climate change of Drysub humid zone (C1) in extremities}

From the Dry sub humid zone $(\mathrm{C} 1)$ the agro climatic potentialities of Solapur and Rajendranagar have been studied during the monsoon, retrieval of monsoon, cold and hot weather season in the extreme dry and wet years along with normal.

Solapur: The climatic agro climatic potentialities of Solapur representing the Dry sub humid zone (C1) showed a distribution of rainfall that produced an $8 \mathrm{~mm}$ water deficiency, with no water surplus in the monsoon season during 1951-80. As a result the normal moisture status maintained its dry sub humid status with $10 \%$ soil wetness and $79 \%$ adequacy. In the retrieval of monsoon season, Solapur recorded $14 \mathrm{~mm}$ rainfall, which produced no water surplus, which forced the moisture status to shift semi aridity (D), with a soil wetness of $36 \%$ and adequacy of $66 \%$.

During the cold weather season $1 \mathrm{~mm}$ rainfall with a $13 \mathrm{~mm}$ water deficit, pushed the moisture status to Aridity (E), with soil wetness of $14 \%$ and adequacy $20 \%$. The Aridity (E) prevailed during the hot weather season with $40 \mathrm{~mm}$ water deficit, $2 \%$ wetness and $11 \%$ adequacy (Table 5). 
Citation: Sivaram B, Sarma AALN (2017) Weekly Seasonal Agro Climatic Potentialities of India and Climate Change in Extremities. J Climatol Weather Forecasting 5: 199. doi:10.4172/2332-2594.1000199

Page 7 of 11

\begin{tabular}{|c|c|c|c|c|c|c|c|c|c|c|c|c|}
\hline Station & Period & Season & $\begin{array}{l}P \\
(\mathrm{~mm})\end{array}$ & $\begin{array}{l}\text { PE } \\
(\mathrm{mm})\end{array}$ & $\begin{array}{l}\mathrm{AE} \\
(\mathrm{mm})\end{array}$ & $\begin{array}{l}\text { D } \\
(\mathrm{mm})\end{array}$ & $\begin{array}{l}S \\
(\mathrm{~mm})\end{array}$ & $\begin{array}{l}\text { Iwh } \\
(\%)\end{array}$ & $\begin{array}{l}\text { Iwa } \\
(\%)\end{array}$ & $\begin{array}{l}\text { Iwm } \\
(\%)\end{array}$ & $\begin{array}{l}\text { Wetness } \\
(\%)\end{array}$ & $\begin{array}{l}\text { Adequacy } \\
(\%)\end{array}$ \\
\hline \multirow[t]{12}{*}{ Junagarh } & $1951-1980$ & June-Sept & 45 & 37 & 31 & 6 & 8 & 22 & 15 & $6(\mathrm{C} 2)$ & 68 & 85 \\
\hline & & Oct-Nov & 7 & 35 & 17 & 18 & 0 & 0 & 53 & $-53(\mathrm{D})$ & 33 & 47 \\
\hline & & Dec-Feb & 1 & 13 & 2 & 11 & 0 & 0 & 86 & $-86(E)$ & 9 & 14 \\
\hline & & Mar-May & 0 & 43 & 1 & 43 & 0 & 0 & 98 & $-98(E)$ & 1 & 2 \\
\hline & Dry year (1991) & June-Sept & 22 & 37 & 19 & 18 & 0 & 1 & 46 & $-45(D)$ & 40 & 54 \\
\hline & & Oct-Nov & 0 & 31 & 4 & 27 & 0 & 0 & 88 & $-88(E)$ & 11 & 12 \\
\hline & & Dec-Feb & 0 & 11 & 1 & 10 & 0 & 0 & 93 & $-93(E)$ & 6 & 7 \\
\hline & & Mar-May & 0 & 43 & 1 & 43 & 0 & 0 & 99 & $-99(E)$ & 1 & 1 \\
\hline & $\begin{array}{l}\text { Wet \& LNSO year } \\
\text { (1988) }\end{array}$ & June-Sept & 77 & 38 & 28 & 10 & 41 & 100 & 26 & 74(B3) & 64 & 74 \\
\hline & & Oct-Nov & 0 & 29 & 15 & 14 & 0 & 0 & 53 & $-53(D)$ & 41 & 47 \\
\hline & & Dec-Feb & 0 & 15 & 1 & 13 & 0 & 0 & 89 & $-89(E)$ & 10 & 11 \\
\hline & & Mar-May & 0 & 45 & 0 & 45 & 0 & 0 & 99 & $-99(E)$ & 1 & 1 \\
\hline \multirow[t]{12}{*}{ Sabour } & $1951-1980$ & June-Sept & 50 & 39 & 37 & 2 & 3 & 7 & 5 & $2(\mathrm{C} 2)$ & 51 & 95 \\
\hline & & Oct-Nov & 14 & 25 & 21 & 3 & 3 & 10 & 19 & $-9(C 1)$ & 76 & 81 \\
\hline & & Dec-Feb & 2 & 6 & 4 & 2 & 0 & 0 & 30 & $-30(C 2)$ & 49 & 70 \\
\hline & & Mar-May & 7 & 43 & 14 & 29 & 0 & 0 & 68 & $-68(E)$ & 16 & 32 \\
\hline & Dry year (1990) & June-Sept & 42 & 40 & 33 & 7 & 6 & 15 & 18 & $-3(\mathrm{C} 1)$ & 66 & 82 \\
\hline & & Oct-Nov & 9 & 25 & 16 & 9 & 0 & 0 & 41 & $-41(D)$ & 43 & 59 \\
\hline & & Dec-Feb & 2 & 7 & 4 & 3 & 0 & 0 & 52 & $-52(D)$ & 36 & 48 \\
\hline & & Mar-May & 12 & 36 & 16 & 20 & 0 & 0 & 56 & $-56(D)$ & 21 & 44 \\
\hline & Wet year (1987) & June-Sept & 103 & 39 & 37 & 1 & 58 & 165 & 4 & $162(A)$ & 87 & 96 \\
\hline & & Oct-Nov & 3 & 26 & 15 & 11 & 0 & 0 & 46 & $-46(D)$ & 46 & 54 \\
\hline & & Dec-Feb & 1 & 7 & 3 & 4 & 0 & 0 & 53 & $-53(D)$ & 41 & 47 \\
\hline & & Mar-May & 8 & 38 & 14 & 24 & 0 & 0 & 63 & $-63(D)$ & 19 & 37 \\
\hline
\end{tabular}

Table 4: Seasonal water budget elements on weekly basis-moist sub humid zone (C2)-extremities.

In the monsoon season of the dry year (1994), there is no water surplus, but an increase in the water deficiency by $11 \mathrm{~mm}$, a moderate depreciation in the rainfall by $15 \mathrm{~mm}(52 \%)$ from the normal have forced the climate to take a shift down ward to semiarid (D) type of climate. It is observed that there is no change in the soil wetness, but $43 \%$ depreciation in moisture adequacy. During the retrieval of monsoon season, though there is an increase in water deficit by $63 \%$, with no water surplus could not change its moisture status of its monsoon season, i.e., semi aridity (D). But soil wetness and adequacy showed a depletion of $42 \%$ and $30 \%$ from their corresponding normality. During the cold weather season, a decrease in water deficit by $15 \%$, with the absence of rainfall changed its moisture status to Aridity (E), with an increase in soil wetness by $92 \%$ and adequacy by $50 \%$. In the hot weather season also Solapur experienced the aridity
(E) due to very less amount of rainfall and high water need. It is observed that soils are $5 \%$ wet with an adequacy of $12 \%$.

On the other hand, in the monsoon season of the wet year (1987), the water surplus showed an increase of $15 \mathrm{~mm}$ due to a fall in the water need by $22 \mathrm{~mm}$ (65\%) from the corresponding normal and as a result the station's climatic status was improved to per humid (A) type. The soil wetness increased by $650 \%$ accompanied by a rise in the soil moisture adequacy by $11 \%$ (Table 5 ). In the retrieval of monsoon season an increased precipitation of $521 \%$ and a decrease in water need by $65 \%$ resulted a high amount of water surplus of $77 \mathrm{~mm}$ which have forced the station's moisture status to per humid (A) type and soils have become wet by $99 \%$ with an adequacy of $100 \%$. In the cold weather season of the wet year (1987), Solapur experienced semiarid (D) climate status due to an increase in water deficit by $10 \mathrm{~mm}$. The 
Citation: Sivaram B, Sarma AALN (2017) Weekly Seasonal Agro Climatic Potentialities of India and Climate Change in Extremities. J Climatol

Page 8 of 11

soils dried to $40 \%$ with adequacy of $43 \%$. Solapur experienced aridity (E), due to a depreciation in water deficit by $75 \%$ with a reduction in water need by $71 \%$ from the corresponding normalcy. The soil wetness and adequacy improved by $250 \%, 118 \%$ respectively from the respective normality. From the aforesaid results it is evident that the moisture status of this station enriched to per humid (A) during the monsoon and retrieval of monsoon seasons of the wet year (1987) and depleted to aridity (E) during the hot weather seasons of both dry and wet years.

\begin{tabular}{|c|c|c|c|c|c|c|c|c|c|c|c|c|}
\hline Station & Period & Season & $\begin{array}{l}P \\
(\mathrm{~mm})\end{array}$ & $\begin{array}{l}\text { PE } \\
(\mathrm{mm})\end{array}$ & $\begin{array}{l}\mathrm{AE} \\
(\mathrm{mm})\end{array}$ & $\begin{array}{l}\text { D } \\
(\mathrm{mm})\end{array}$ & $\begin{array}{l}S \\
(\mathrm{~mm})\end{array}$ & $\begin{array}{l}\text { Iwh } \\
(\%)\end{array}$ & $\begin{array}{l}\text { Iwa } \\
(\%)\end{array}$ & $\begin{array}{l}\text { Iwm } \\
(\%)\end{array}$ & $\begin{array}{l}\text { Wetness } \\
(\%)\end{array}$ & $\begin{array}{l}\text { Adequacy } \\
\text { (\%) }\end{array}$ \\
\hline \multirow[t]{12}{*}{ Solapur } & $1951-1980$ & $\begin{array}{l}\text { June- } \\
\text { Sept }\end{array}$ & 31 & 34 & 27 & 8 & 0 & 0 & 21 & $-21(C 1)$ & 10 & 79 \\
\hline & & Oct-Nov & 14 & 26 & 18 & 8 & 0 & 0 & 34 & $-34(D)$ & 36 & 66 \\
\hline & & Dec-Feb & 1 & 17 & 3 & 13 & 0 & 0 & 80 & $-80(E)$ & 14 & 20 \\
\hline & & Mar-May & 4 & 45 & 5 & 40 & 0 & 0 & 89 & $-89(E)$ & 2 & 11 \\
\hline & $\begin{array}{l}\text { Dry } \\
(1994)\end{array}$ & $\begin{array}{l}\text { June- } \\
\text { Sept }\end{array}$ & 16 & 34 & 16 & 19 & 0 & 0 & 55 & $-55(D)$ & 10 & 45 \\
\hline & & Oct-Nov & 15 & 27 & 14 & 13 & 0 & 0 & 54 & $-54(D)$ & 21 & 46 \\
\hline & & Dec-Feb & 0 & 15 & 5 & 11 & 0 & 0 & 70 & $-70(E)$ & 27 & 30 \\
\hline & & Mar-May & 3 & 44 & 5 & 39 & 0 & 0 & 88 & $-88(E)$ & 5 & 12 \\
\hline & $\begin{array}{l}\text { Wet year } \\
(1987)\end{array}$ & $\begin{array}{l}\text { June- } \\
\text { Sept }\end{array}$ & 31 & 12 & 10 & 1 & 15 & 145 & 12 & $133(A)$ & 75 & 88 \\
\hline & & Oct-Nov & 87 & 9 & 9 & 0 & 77 & 894 & 0 & 894(A) & 99 & 100 \\
\hline & & Dec-Feb & 2 & 14 & 3 & 10 & 0 & 7 & 57 & $-50(D)$ & 40 & 43 \\
\hline & & Mar-May & 5 & 13 & 3 & 10 & 0 & 0 & 76 & $-76(E)$ & 7 & 24 \\
\hline Rajendranagar & $1951-1980$ & $\begin{array}{l}\text { June- } \\
\text { Sept }\end{array}$ & 32 & 38 & 30 & 8 & 0 & 0 & 20 & $-20(C 1)$ & 17 & 80 \\
\hline & & Oct-Nov & 10 & 31 & 15 & 17 & 0 & 0 & 56 & $-56(D)$ & 20 & 44 \\
\hline & & Dec-Feb & 1 & 17 & 2 & 15 & 0 & 0 & 90 & $-90(E)$ & 2 & 10 \\
\hline & & Mar-May & 5 & 43 & 5 & 38 & 0 & 0 & 88 & $-88(E)$ & 1 & 12 \\
\hline & $\begin{array}{ll}\text { Dry } & \text { year } \\
(1984) & \end{array}$ & $\begin{array}{l}\text { June- } \\
\text { Sept }\end{array}$ & 20 & 34 & 17 & 17 & 2 & 8 & 48 & $-40(D)$ & 26 & 52 \\
\hline & & Oct-Nov & 10 & 22 & 10 & 12 & 0 & 0 & 58 & $-58(D)$ & 26 & 42 \\
\hline & & Dec-Feb & 0 & 14 & 0 & 14 & 0 & 0 & 96 & $-96(E)$ & 4 & 4 \\
\hline & & Mar-May & 4 & 43 & 4 & 39 & 0 & 0 & 90 & $-90(E)$ & 1 & 10 \\
\hline & $\begin{array}{l}\text { Wet year } \\
(1985)\end{array}$ & $\begin{array}{l}\text { June- } \\
\text { Sept }\end{array}$ & 55 & 34 & 23 & 11 & 31 & 104 & 32 & $71(\mathrm{~B} 3)$ & 41 & 68 \\
\hline & & Oct-Nov & 8 & 19 & 8 & 12 & 0 & 0 & 65 & $-65(D)$ & 20 & 35 \\
\hline & & Dec-Feb & 0 & 16 & 1 & 15 & 0 & 0 & 92 & $-92(E)$ & 4 & 8 \\
\hline & & Mar-May & 3 & 44 & 3 & 41 & 0 & 0 & 92 & $-92(E)$ & 1 & 8 \\
\hline
\end{tabular}

Table 5: Seasonal water budget elements on weekly basis-dry sub humid zone (C1) extremities.

Rajendranagar: The mean weekly agro climatic potentialities of Rajendranagar in the monsoon season, retrieval of monsoon season, cold and hot weather seasons during the long term, dry and wet situations have been presented in Table 5. It is evident that there is an increase in water deficit by $9 \mathrm{~mm}$ and water surplus by $2 \mathrm{~mm}$ due to depreciation in rainfall by $12 \mathrm{~mm}$ and water need by $4 \mathrm{~mm}$ from the normality during the monsoon season of Dry year (1984). As a result the moisture status of this status depleted to semiarid (D), accompanied by an improvement in soil wetness by $53 \%$ and decrease in moisture adequacy by $35 \%$. In the monsoon withdrawal season, depreciation in water deficit by $29 \%$ accompanied by depreciation in water need by $33 \%$ from their normalcy forced the moisture status to 
shift to semi aridity (D), but soils improved their wetness by $30 \%$ and moisture adequacy dropped by $5 \%$. In the cold weather season of dry year (1984) Rajendranagar experienced Aridity (E), with $100 \%$ increase in soil wetness and $60 \%$ decrease in soil moisture adequacy from the corresponding normality. In the hot weather season of the dry year moisture status depleted to aridity. Due to high water deficits and water needs the moisture adequacy depleted to $10 \%$ in the hot weather season of dry year.

In the monsoon season of the wet year (1985), experienced a rainfall which is almost twice that of the normal. As a result, the water surplus rose by $31 \mathrm{~mm}$ and the water need depreciated by $4 \mathrm{~mm}$ (11\%) from the normal and these were responsible for the climatic shift of the station to the third humid (B3) type, and enrichment in soil wetness by $141 \%$ with depletion in adequacy by $15 \%$. In the monsoon withdrawal season, moisture status shifted to semi aridity (D) due to subnormal rainfall that resulted to absence of water surplus. As a result soil wetness maintained its normality, but $20 \%$ depreciation in soil moisture adequacy is observed. During the cold and hot weather seasons, Rajendranagar experienced Aridity (E) due to the depreciation in rainfall that could not meet the water demand, which resulted an increase in water deficit.

From the aforesaid discussion it can be concluded that the moisture status of this station enriched to third humid (B3) during the monsoon season of wet year (1985). The climate status depleted to aridity (E) during the cold and hot weather seasons of long term, dry and wet years.

\section{Mean weekly seasonal climate change of semiarid zone (D) in extremities}

The mean weekly water budget elements for the four seasons in the long term, extreme dry and wet years are presented here for the two stations Jodhpur and Aduthurai representing the semiarid zone, from the climatic spectrum of India.

Jodhpur: It is evident from the water balance studies (Table 6) that during the monsoon seasons of all the extremities the rainfall distribution is subnormal and could not meet the potential water need, except in the wet year (1990). In the extreme dry situation (1987), which is also the ENSO year, there is no water surplus. The depreciation of rainfall by $16 \mathrm{~mm}$, accompanied by an increase in potential water need by $3 \mathrm{~mm}$ increased the water deficit by $20 \mathrm{~mm}$ from the respective normality. As a consequence the moisture status depleted to aridity (E). The soils are wet by $1 \%$ and adequate by $8 \%$. In the cold and hot weather seasons of the Dry \& ENSO year (1987), the moisture status depleted to aridity (E), due to subnormal rainfall.

The monsoon season of the wet year (1990), witnessed a water surplus of $23 \mathrm{~mm}$ due to the heavy rainfall of $44 \mathrm{~mm}$, which is $24 \mathrm{~mm}$ (120\%) higher than the normal. As a result, the moisture status improved to dry sub humid (C1) type of climate. The soil wetness and moisture adequacy showed an increase by $725 \%$ and $4 \%$ respectively in the wet year from their normality. During the post monsoon season, cold and hot weather seasons of the wet year (1990), Jodhpur witnessed subnormal rainfall, which could not meet the potential water need. As a result, the climate status depleted to aridity (E), with soil wetness by $1 \%$. From this analysis it can be concluded that moisture status improved to dry sub humid (C1) and depreciated to aridity (E) during the monsoon season of Wet year and dry years respectively. In all other seasons of long term, dry \& ENSO and Wet years the climate status dropped to aridity (E).

Aduthurai: From the water balances of Aduthurai (Table 6), it is clear that the distribution of rainfall is subnormal, during the monsoon period of dry year (1994) that could not meet the demand. As a result, the moisture status depleted to aridity (E), with soil wetness of $1 \%$ and adequacy $9 \%$. During the retrieval of monsoon season of dry year (1994)), the climate status enriched to first humid (B1), due to huge amount of rainfall of $54 \mathrm{~mm}, 33 \mathrm{~mm}$ water need and an increase in water surplus by $20 \mathrm{~mm}$, along with a depreciation in soil wetness by $18 \%$ and soil moisture adequacy by $38 \%$ from the corresponding normalcy.

During the cold weather season of Dry year, the climate status of Aduthurai depleted to dry sub humid (C1). Soil wetness decreased to $73 \%$, with an adequacy of $79 \%$ which may be due to the depreciation in the rainfall by $5 \mathrm{~mm}$ from the corresponding normality, which increased the water deficit.

The climate status further depleted to aridity (E) in the hot weather season of dry year (1994), which may be due to less amount of rainfall and high water need.

The monsoon season of wet year (1996) recorded a water surplus of $5 \mathrm{~mm}$, due to an amount of rainfall $31 \mathrm{~mm}$. As a consequence the moisture status was improved and the climate was shifted into dry sub humid (C1) type. The soil wetness and soil moisture adequacy were improved by $37 \%$ and $29 \%$ respectively from the corresponding normality.

During the retrieval of monsoon season of this year, this station registered a rainfall of $49 \mathrm{~mm}$ with a water need $36 \mathrm{~mm}$, as a result the water surplus increased by $2 \mathrm{~mm}$ from its normality. As a result the climate is force to shift to dry sub-humid (C2) with a soil wetness of $41 \%$ and soil moisture adequacy $77 \%$.

In the cold weather season of the wet year (1996), Aduthurai experienced Per humid (A) status, with $46 \%$ soil wetness and $48 \%$ adequacy due to an increase in the rainfall by $28 \mathrm{~mm}$ from its normality, with stationary potential water need, which resulted $43 \mathrm{~mm}$ water surplus.

During the hot weather season of the wet year, Aduthurai witnessed aridity (E), due to the depreciation in precipitation and increase in water need that resulted to absence of water surplus and increase in water deficit. The soil wetness and moisture adequacy reduced to $3 \%$ and $16 \%$ respectively.

From the above discussion it can be concluded that the climate status of Jodhpur enriched to dry sub humid (C1) during the monsoon season of the wet year (1990) and depleted to aridity (E) in all the seasons of dry and wet years. On the other hand, Aduthurai shifted its climate status to first humid (B1) and moist sub humid (C2) in the retrieval of monsoon season of dry and wet years. During cold weather season of dry year (1994), Aduthurai experienced dry sub humid (C1) and improved its climate status to per humid (A) in the wet year (1996). Both the stations that hail from the semiarid zone shifted their climate status to aridity (E), in the hot weather season of the long term, dry and wet years. 
Citation: Sivaram B, Sarma AALN (2017) Weekly Seasonal Agro Climatic Potentialities of India and Climate Change in Extremities. J Climatol Weather Forecasting 5: 199. doi:10.4172/2332-2594.1000199

Page 10 of 11

\begin{tabular}{|c|c|c|c|c|c|c|c|c|c|c|c|c|}
\hline Station & Period & Season & $\begin{array}{l}P \\
(\mathrm{~mm})\end{array}$ & $\begin{array}{l}\text { PE } \\
(\mathrm{mm})\end{array}$ & $\begin{array}{l}\text { AE } \\
(\mathrm{mm})\end{array}$ & $\begin{array}{l}D \\
(\mathrm{~mm})\end{array}$ & $\begin{array}{l}S \\
(\mathrm{~mm})\end{array}$ & $\begin{array}{l}\text { Iwh } \\
\text { (\%) }\end{array}$ & $\begin{array}{l}\text { Iwa } \\
\text { (\%) }\end{array}$ & $\begin{array}{l}\text { Iwm } \\
\text { (\%) }\end{array}$ & $\begin{array}{l}\text { Wetness } \\
(\%)\end{array}$ & $\begin{array}{l}\text { Adequacy } \\
\text { (\%) }\end{array}$ \\
\hline \multirow[t]{12}{*}{ Jodhpur } & $1951-1980$ & June-Sept & 20 & 41 & 20 & 21 & 0 & 0 & 50 & $-50(D)$ & 4 & 50 \\
\hline & & Oct-Nov & 1 & 29 & 1 & 29 & 0 & 0 & 98 & $-98(E)$ & 1 & 2 \\
\hline & & Dec-Feb & 1 & 7 & 1 & 7 & 0 & 0 & 93 & $-93(E)$ & 1 & 7 \\
\hline & & Mar-May & 1 & 42 & 1 & 41 & 0 & 0 & 96 & $-96(E)$ & 1 & 4 \\
\hline & $\begin{array}{l}\text { Dry \& ENSO year } \\
\text { (1987) }\end{array}$ & June-Sept & 4 & 44 & 4 & 41 & 0 & 0 & 92 & $-92(E)$ & 1 & 8 \\
\hline & & Oct-Nov & 0 & 32 & 0 & 32 & 0 & 0 & 100 & $-100(E)$ & 1 & 0 \\
\hline & & Dec-Feb & 1 & 7 & 1 & 6 & 0 & 0 & 84 & $-84(E)$ & 2 & 16 \\
\hline & & Mar-May & 3 & 44 & 3 & 41 & 0 & 0 & 94 & $-94(E)$ & 1 & 6 \\
\hline & Wet year (1990) & June-Sept & 44 & 41 & 21 & 20 & 23 & 47 & 48 & $0(\mathrm{C} 1)$ & 33 & 52 \\
\hline & & Oct-Nov & 0 & 14 & 1 & 12 & 0 & 0 & 88 & $-88(E)$ & 10 & 12 \\
\hline & & Dec-Feb & 2 & 9 & 2 & 7 & 0 & 0 & 83 & $-83(E)$ & 3 & 17 \\
\hline & & Mar-May & 1 & 42 & 2 & 40 & 0 & 0 & 96 & $-96(E)$ & 1 & 4 \\
\hline \multirow[t]{12}{*}{ Aduthurai } & 1951-1980 & June-Sept & 18 & 38 & 18 & 20 & 0 & 0 & 51 & $-51(D)$ & 1 & 49 \\
\hline & & Oct-Nov & 58 & 33 & 32 & 1 & 7 & 25 & 2 & 23(B1) & 49 & 98 \\
\hline & & Dec-Feb & 19 & 20 & 17 & 3 & 9 & 47 & 14 & 32(B1) & 80 & 86 \\
\hline & & Mar-May & 8 & 42 & 12 & 30 & 0 & 0 & 71 & $-71(E)$ & 12 & 29 \\
\hline & Dry year (1994) & June-Sept & 4 & 38 & 4 & 34 & 0 & 0 & 91 & $-91(E)$ & 1 & 9 \\
\hline & & Oct-Nov & 54 & 33 & 18 & 15 & 20 & 75 & 40 & 35(B1) & 40 & 60 \\
\hline & & Dec-Feb & 14 & 20 & 16 & 4 & 3 & 15 & 21 & $-6(C 1)$ & 73 & 79 \\
\hline & & Mar-May & 4 & 42 & 10 & 33 & 0 & 0 & 77 & $-77(\mathrm{E})$ & 13 & 23 \\
\hline & Wet year (1996) & June-Sept & 31 & 37 & 23 & 14 & 5 & 15 & 37 & $-22(C 1)$ & 37 & 63 \\
\hline & & Oct-Nov & 49 & 36 & 27 & 9 & 9 & 27 & 23 & $4(\mathrm{C} 2)$ & 41 & 77 \\
\hline & & Dec-Feb & 47 & 20 & 9 & 11 & 43 & 245 & 52 & 193(A) & 46 & 48 \\
\hline & & Mar-May & 6 & 42 & 7 & 35 & 0 & 0 & 84 & $-84(E)$ & 3 & 16 \\
\hline
\end{tabular}

Table 6: Seasonal water budget elements on weekly basis-semi arid zone (D)-extremities.

\section{Summary and Conclusion}

In the monsoon period, during the three study periods 1951-1980, 1981-1991, and 1992-1998 the All India climate witnessed first, fourth and third humid (B1, B4 and B3) status respectively. In the retrieval of monsoon season, All India moisture status depleted to dry sub humid (C1)in the years 1951-1980 and 1981-1991, whereas in 1992-1998 All India witnessed moist sub humid (C2) climate. Among the three study periods the All India climate changed to semiarid (D) during the cold weather seasons of 1951-1980 and 1981-1991, with a shift to dry sub humid (C1) in 1992-98. The moisture status depreciated to arid (E) during the hot weather seasons of 1951-1980, 1981-1991 and semiarid (D) in 1992-1998.
Tocklai that hails from per humid climate zone depleted to second and fourth humid climate during the monsoon season of dry and wet years respectively. In the retrieval of monsoon season of long term, dry and wet years the climate status shifted to moist sub humid (C2) and dry sub humid (C1). In the cold and hot weather seasons of the study period, this station's moisture status shifted to dry sub humid (C1) and moist sub humid $(\mathrm{C} 2)$ respectively.

Karjat is consistent and maintained its per humid (A) status in monsoon season but shifted to moist sub humid (C2) and dry sub humid (C1)in the retrieval and then dropped to Arid (E) in the cold and hot weather seasons during the Dry and Wet years.

In the extreme dry year, Adhartal that hails from humid zone shifted to dry sub humid (C1) in monsoon season, and remained in the same status during retrieval of monsoon period and cold weather 
season, shifted to Arid (E) status in the hot weather season. During the wet year Adhartal improved its moisture status to per humid (A) but witnessed aridity during the retrieval, cold and hot weather seasons.

Rudrur a representative of humid zone depleted to dry sub humid (C1) and enriched to per humid (A) during the monsoon season of dry and wet years. During retrieval of monsoon season the climate status dropped to semi aridity (D), and during cold and hot weather seasons of dry and wet years, its climate status depleted to aridity (E).

Junagarh's moisture status depleted to semiarid (D) and enriched to third humid (B3), during the monsoon season of dry and wet years respectively. In the monsoon retrieval season the moisture regime shifted to semiarid (D) during the long term and wet years of study and experienced aridity (E) during the same season of dry year. In the rest of the seasons of the study period Junagarh's moisture status depleted to aridity (E). Sabour improved its moisture regime to per humid (A) and dropped to dry sub humid (C1) in the monsoon period of wet and dry years respectively. In the rest of the seasons of the dry and wet years Sabour experienced semi aridity (D).

The moisture status of Jodhpur improved to dry subs humid (C1) and depreciated to aridity (E) during the monsoon season of wet year and dry years respectively. In all other seasons of long term, dry \& ENSO and wet years the climate status dropped to aridity (E).

Aduthurai shifted its climate status to first humid (B1) and moist sub humid (C2) in the retrieval of monsoon season of dry and wet years. During cold weather season of dry year (1994), Aduthurai experienced dry sub humid (C1) and improved its climate status to per humid (A) in the wet year (1996).

\section{Acknowledgements}

Authors acknowledge Additional Director General of Meteorology (Research), PUNE for supplying the meteorological data for the study period.

\section{References}

1. Gadgil S (1996) Climate change and agriculture-An Indian perspective In Climate Variability and Agriculture pp: 1-18.

2. Food and Agriculture Organization (FAO) (1997) Impact of El Niño on Agriculture, Fisheries and Forestry a Report.
3. Richard MA, Chi-Chung C, Bruce A McCarl, Rodney F (1999) The economic consequences of ENSO events for agriculture. Clim Res 13: 165-172.

4. Das HP, Goankar SB (2000) Impact of weather on low land rice cultivation and planning decisions over humid tropical India. Mausam 51: 261-268.

5. Kashyaji A (2002) Influence of Meteorological parameters on performance of rain fed Cropping Systems. Mausam 53: 1 .

6. Deng X (2010) Impacts of El Nino-Southern Oscillation events on China's rice production. J Geographys Sci 20: 3-16.

7. Sarma AALN, Vizayabhaskar (2013) Monsoon season soil wetness over India-ENSO and LNSO Events. J Ind Geophys Union 17: 383-402.

8. Krishna K, Singh GP, Sekhar MS (2015) The Influence of seasonal teleconnection patterns on the cryosphere of Antarctic and Northern Himalayas. Int J Earth Atmos Sci 2: 80-89.

9. Sikka DR (1980) Some aspects of large scale fluctuations of summer monsoon rainfall over India in relation to fluctuations in the planetary and regional scale circulation parameters. Proc Indian Acad Sci 89: 179-195.

10. Krishnamurthy TN (1985) Summer Monsoon Experiment: A review. Mon Weather Rev 113: 1590-1626.

11. Mooley DA, Parthasarathy B, Pant GB (1986) Relationships between India summer rainfall and location of the ridge at $500 \mathrm{hPa}$ level along $75^{\circ}$ E. J Cli App Met 25: 633-640.

12. Shukla J (1987) Interannual variability of monsoon "In Monsoons". J Weley \& Sons pp: 339-463.

13. Sarma AALN, Srinivas S, Karthikeya A (2005) Studies on Aberrations in Climate Impacts-Water Balance Model. Ind Geophys Union 9: 205-214.

14. Bhalme HN, Mooley DA, Jadhav SK (1984) Fluctuations in drought/flood area over India and relationships with the Southern Oscillations. Monthly Weather Rev 111: 86-94.

15. Sarker RP (1987) Proc Int Conf On tropical micro met and air pollution, Indian Institute of Technology, New Delhi, India.

16. Chaudhury A, Mhasawade SV (1991) Variations in meteorological floods during summer monsoon over India. Mausam 42: 167-170.

17. Thornthwaite CW, Mather JR (1955) The Water Balance. Publ in Clim Drexel Instt Tech 8: 1.

18. Gore PG, Thapliyar V (1999) Occurrence of Dry and Wet weeks over Maharashtra. Mausam 51: 1.

19. Carter DB, Mather JR (1966) Climatic Classification for Environmental Biology. Publi Incline Inst 19: 341- 352. 